\title{
Bio-Compost Behaviour as Soil Additive by Food Waste Pretreatment on the Growth of Abelmoschus esculentus L.: A Systematic Review
}

\author{
Miiraa Muruga, Veknesh Arumugam and Muhammad Heikal Ismail* \\ Department of Chemical and Environmental Engineering, Faculty of Engineering, Universiti Putra Malaysia, \\ 43400 Serdang, Malaysia
}

\begin{abstract}
Food waste (FW) has always been a significant issue faced by almost all countries worldwide. The rise in FW does not only influence one's food supply, yet the greenhouse gas $(\mathrm{GHG})$ emission such as methane $\left(\mathrm{CH}_{4}\right)$ and carbon dioxide $\left(\mathrm{CO}_{2}\right)$ gas leads to global warming and health issues. This paper reviews the primary FW treatments available in all countries. Most advanced countries have accomplished that the least cost and most efficient FW treatment is composting. Among all the composting methods available, vermicomposting (VC) that uses redworms (Eisenia fetida) produces nutrients rich biocompost, as proven in the existing literature. Furthermore, bio-compost produced by the VC method nourishes plant growth. In this study, the primary research data sources are 78 scientific articles over the last few years. This research is the consensus on VC as the FW treatment. Besides, briefly discuss the

ARTICLE INFO

Article history:

Received: 25 April 2021

Accepted: 26 July 2021

Published: 29 September 2021

DOI: https://doi.org/10.47836/pjtas.44.4.07

E-mail addresses:

miiraamuruga@gmail.com (Miiraa Muruga)

viknesharumugam2@gmail.com (Veknesh Arumugam)

heikal@upm.edu.my (Muhammad Heikal Ismail)

FW pretreatment methods, the effect of bio-compost on soil properties, and their corresponding effects on the growth of Abelmoschus esculentus L.

Keywords: Abelmoschus esculentus L., food waste treatment, pretreatment methods, soil additive, vermicomposting
\end{abstract}

*Corresponding author 


\section{INTRODUCTION}

Sustainable Development Goals (SDGs), implemented in 2015, are meant to be accomplished by 2030. Among the 17 goals listed, precisely in the 12 th target, the concept of food loss and waste management were considered. It stipulates that by 2030 , food waste (FW) will be halved globally at both the consumer and trade levels. Besides, the number of food losses throughout the supply chain should be reduced, including losses in post-harvest areas (Gao et al., 2017).

It is due to the FW that significantly contributes to greenhouse gas (GHG) emissions. It accounts for around twenty percent of overall GHG emissions in developing countries (Vinoth Kumar \& Kasturi Bai, 2008). Therefore, many treatments have been proposed and conducted to reduce the environmental effects of FW products (Gao et al., 2017). For instance, landfill, composting, incineration, and anaerobic digestion are the common treatment practiced.

Composting is the natural method of decomposition of organic matter that produces bio-compost, increasing soil fertility. Among the other FW treatments, composting can be done in various ways. Aerobic digestion, compost of bin mechanical aerated pile, vermicomposting (VC), vessel composting, and windrow is some of the proven methods (Sundberg, 2005).

$\mathrm{VC}$ is a method that can enhance the beneficial use of FW into rich soil amendments and nutrients (Arancon et al.,
2003). VC is a composting method that uses red worms for the degradation of foodstuffs into bio-compost. Good quality composts can be produced by VC (Sundberg, 2005). However, redworms have sensitive skin, and these delicate skins can only live under certain circumstances in the environment. Findings stated that acidic conditions might harm the redworms (Pierre et al., 2020).

Food consumption by redworms plays a vital role in producing high-quality biocompost. Different $\mathrm{pH}$ of $\mathrm{FW}$ treated by the VC method using redworms produces a different standard of bio-compost. The VC method can also give significant results for bio-compost with different pretreatment methods on FW. Researchers agreed that high-quality bio-compost obtained from VC could improve soil nutrients (Shen et al., 2015).

Hence, this review paper consists of few parts; where the first part of the review is the properties of $\mathrm{FW}$ in terms of the $\mathrm{pH}$ value followed by the FW pretreatment methods. The next part comprises the FW treatments available. Bio-compost behavior on soil properties is discussed further in the next part of the review. The last part of the review consists of the nutrient required to grow the lady's finger (Abelmoschus esculentus L.) by bio-compost as the organic fertilizer.

\section{PROPERTIES OF FOOD WASTE}

One of the largest waste generated in Malaysia, which is almost half of the entire volume of waste generated daily, is known as the FW (Arvanitoyannis et al., 2008), according to a study published by 
the National Solid Waste Management Department in 2012. The production quality of this amount of $\mathrm{FW}$ is about $\$ 800$ billion where it accounts for almost $7 \%$ of the global annual GHG emissions (Slorach et al., 2019).

At sites, approximately 2.29 million tons of wasted food are sent to landfills globally, resulting in around 11 million tons of $\mathrm{CO}_{2}$ emissions (Hao et al., 2015). Globally, the cost of FW is projected to be approximately USD 2.6 trillion, including a portion of USD 1 trillion is mainly on GHG emissions (Jain et al., 2018). Although consumers are to be blamed, FW also occurs because of distributors, restaurants, and marketers (Gao et al., 2017).

Among the FW from kitchen scrap, fruit peels, or even expiry date food items, it can be signified into strong and weak acidic FW. Strong acid FW is the FW with a $\mathrm{pH}$ of 1 to 3 , whereas weak acid $\mathrm{FW}$ is the FW with a pH of 4 to 6 (Sundberg et al., 2013). Due to the suitable and adequate surroundings for redworms to carry out their composting process, the $\mathrm{pH}$ of $\mathrm{FW}$ in VC plays a significant role (Boulter et al., 2000). Therefore, suitable $\mathrm{pH}$ can increase the quality of bio-compost produced.

Composting of traditional agricultural waste can be enhanced with additives. Additive items such as alkaline minerals, lime, and ash may also contain $\mathrm{pH}$-balancer compounds, which raise compost $\mathrm{pH}$ levels (Sasaki et al., 2003). Compost from alkaline items can advertise micro-organism behavior due to potential inhibitory effects due to high alkalinity (Yu \& Huang, 2009).
When composting wastage, a high acidity stage at the beginning of the process is often possible (Sundberg, 2005).

However, extended low pH condition leads to a problem in FW composting. It has been proven in Scandinavia from past research. The slow decomposition of FW prolongs the composting period (Wong et al., 2009). These are the effects of the dominating acids contained in the FW. The $\mathrm{pH}$ values of bio-compost were generally neutral and are provided by the processing of $\mathrm{CO}_{2}$ and organic acids released during microbial activity (Albanell et al., 1988).

\section{FOOD WASTE PRETREATMENT METHODS}

To make the therapy more successful, every treatment performed has its pretreatment process. Pretreatment of the organic substrate was first introduced at the beginning of the 1920s and, owing to the intensive use of energy or chemicals, was regarded as the costliest phase. Study papers relating to pretreatment approaches are known to increase tremendously compared to 1990 results (Yin et al., 2016). Apart from this, pretreatment methods affect bio-compost quality.

Specific pretreatment procedures for solid waste can be used, such as mechanical (ultrasound and lysis), thermal, chemical, and biological pretreatment (Tun \& Juchelková, 2019). Thermal and chemical, accompanied by ultrasonic and microwave pretreatment, are also some of the pretreatments in use. However, the pretreatment results of FW are different and depend greatly on the process 
for pretreatment and the composition of the substrates (Krishna \& Kalamdhad, 2014). All the pretreatment stated falls under physical, chemical, physicochemical, and biological pretreatments.

The approach by pretreatment methods and subsequent bioprocessing approaches can therefore be preferred. Most of the chemical, mechanical, and thermal processes research are concerned (Delgenes et al., 2003). The rest may be based on a synthesis of many approaches (Salihu \& Alam, 2016). Pretreatment involving alkaline solution has a higher possibility of affecting the quality of bio-compost due to the $\mathrm{pH}$ condition for worms.

\section{Physical Pretreatment}

Without any chemical reactions or additional microorganisms, the pretreatment process is called physical pretreatment (Zheng et al., 2014). The purpose of this pretreatment is to minimize the particle size and increases the surface area of FW. It is also known as mechanical pretreatment that reduces the FW particles without generating any products. Perhaps, one of the significant disadvantages is that the process requires energy. Advantages of this pretreatment include less operational costs, high disintegration potential, uses simple operating process, and no transformation in chemical properties involved (Bernstad \& la Cour Jansen, 2012). The common operation usually depends on the robustness that acts on the FW surfaces. Some of the common physical pretreatments are discussed below.
Milling Pretreatment. In this technique, the particle size of FW is reduced. Thus, it promotes the disarrangement of the lignocellulosic material crystallinity. The method provides a reduction of the FW that is below $2.0 \mathrm{~mm}$. Hence, it helps in increasing the particle surface area for a continuous hydrolysis method (Paritosh et al., 2017). By implementing this pretreatment method, the processing time has been highly reduced. Also, the amount of water consumed is reduced. However, energy consumption for this method is still high (Seidl \& Goulart, 2016).

Ultrasonication Pretreatment. Ultrasonication is one of the efficient in FW pretreatment. It is a technique that uses ultrasonic waves that stimulates pressure deviation (Batista Meneses et al., 2020). This pretreatment is combined many processes that involve chemical reactions, combustion, shearing, and pyrolysis. This combination increases the efficiency of the pretreatment method. Apart from that, Seidl and Goulart (2016) have described that the productivity of this pretreatment truly depends on the properties of FW.

Extrusion Pretreatment. This method mainly focuses on producing objects. FW is forced into a frame with the preferred size and shape. When the FW exits the frame, it usually experiences expansion (Batista Meneses et al., 2020). FW has its effect when this pretreatment method is introduced. For instance, minimization in the size of the material automatically increases its 
surface area, and visible transformation in FW occurs. Process efficiency is improved by one of the common ways practiced: combining extrusion methods with any acid or alkaline treatments (Duque et al., 2017).

Thermal Pretreatment. One of the fastest pretreatment methods is thermal pretreatment. Another significant gain is that solid FW is sterilized so that unwanted microbes that may impact methane $\left(\mathrm{CH}_{4}\right)$ or hydrogen rates are deactivated. Thermal pretreatment is the most general method of application in which biomass substrates are solubilized by heat. It was used at 50 to $270{ }^{\circ} \mathrm{C}$ at temperatures for a long time to boost organic particulate disintegration (Deepanraj et al., 2017). Results indicate that the solubility and biodegradability of organic compounds are considerably improved by heat pretreatment.

The $\mathrm{pH}$ control can further boost the performance and better understanding of FW thermal pretreatment. During external auxiliary energy sources, the dewatering option is called thermal drying (Ragazzi et al., 2007). Gandhi et al. (2018) investigated the effect of thermal pretreatment on kitchen waste at various temperatures $\left(37^{\circ} \mathrm{C}, 50\right.$ ${ }^{\circ} \mathrm{C}$, and $60{ }^{\circ} \mathrm{C}$ ) to study the influence on hydrolysis. Therefore, pretreatment at 60 ${ }^{\circ} \mathrm{C}$ was shown to be beneficial, with a total chemical oxygen demand (TCOD) removal rate of $79.2 \%$. In addition, oven drying makes the dehydration process efficient in a short duration (Salihu \& Alam, 2016).

\section{Physicochemical Pretreatment}

Physicochemical pretreatment has effects on either the physical or chemical properties of FW. Steam explosion pretreatment, liquid hot water pretreatment, supercritical $\mathrm{CO}_{2}$ explosion pretreatment, microwave pretreatment, and plasma pretreatment are examples of physical-chemical pretreatment.

Steam Explosion Pretreatment. This pretreatment is similar to hydrothermal pretreatment. The FW is briskly heated in a reactor filled with saturated steam at high temperatures and pressure. The FW is kept in the reactor for seconds to several minutes based on the FW properties (Sun et al., 2009). The vapor formed in the reactor penetrates the FW and breaks the chemical bonds. The most significant advantage of this technique is that it is an environmentally friendly method. However, since it is still a developing technology, improvements in reactor design need to be explored. Besides, the operational mode of the reactor and the addition of catalysts enhances the FW pretreatment (Song et al., 2018).

Liquid Hot Water Pretreatment. This pretreatment retains the temperature of the liquid water at $140{ }^{\circ} \mathrm{C}$ and $240^{\circ} \mathrm{C}$. The water can easily invade the cell wall and break down the cells at high temperatures (Xu et al., 2019). The benefits are that no chemical additives are introduced in this method. Also, low toxicity compounds are not formed. Besides, a common reactor can be used instead of a corrosion-resistant reactor 
due to the low formation of byproducts ( $\mathrm{Yu}$ \& Huang, 2009).

\section{Supercritical Carbon Dioxide Explosion}

Pretreatment. This pretreatment uses supercritical $\mathrm{CO}_{2}$ because it is a green solvent that is not flammable and volatile. After the pretreatment, solid-liquid extraction is conducted because the solvent can be removed easily. Typical process variables such as the flow and temperature are to be adjusted to maximize the yields. Besides, combining this method with ultrasonication and extrusion gives better results (Batista Meneses et al., 2020).

Microwave Pretreatment. Microwave pretreatment uses microwaves to irradiate lignocellulosic materials (Kamaruzzaman et al., 2018). This pretreatment method can speed up all the biological, physical, and chemical processes due to the high heat supply and higher collision rate of ions (Batista Meneses et al., 2020). However, this method is strongly dependent on the properties of FW.

Plasma Pretreatment. The addition of ozone $\left(\mathrm{O}_{3}\right)$ in this plasma pretreatment helps in the lignin degradation process in FW. In addition, it helps to enhance the following process, which is the hydrolysis process (Kamaruzzaman et al., 2018). This pretreatment is also called ozonation pretreatment. Plasma produces highly reactive compounds that can degrade cellulose into glucose. Thus, this pretreatment can be easily break down the complex structure of lignocellulosic materials (Vanneste et al., 2017).

\section{Biological Pretreatment}

Biological pretreatment can be classified as environmentally friendly and requires less capital investment. However, perhaps, this pretreatment is only effective in controlled environmental conditions and requires a longer time for the growth of microbes. Compared with the other methods, the biological methods below usually require low energy and chemical input. However, the longer pretreatment time and the release of odor are some of its main disadvantages. Examples of biological pretreatments are enzymatic pretreatment, microbial consortium pretreatment, and fungal pretreatment (Batista Meneses et al., 2020).

Microbial Consortia. Some advantages of using the microbial consortia method are that it increases functional robustness, has high productivity, and has high stability when biochemically degrading the FW (Batista Meneses et al., 2020). However, by using this method, FW degradation rates and physicochemical changes are easily afflicted. Therefore, it is known as one of the main disadvantages of the method. Those factors are the physical, enzyme activity, chemical, and biological factors (Sukumaran et al., 2005).

Fungal Species Pretreatment. Fungi are known as a type of microorganisms where the cell walls are made up of chitin. Some of 
the species are brown rot, soft rot, and white rot. These fungi are characterized based on their capability to break down the structures in different types of FW. One of the major advantages of implementing this method is the low usage of chemical reagents and low energy consumption. However, the disadvantage is that the incubation period is long (Batista Meneses et al., 2020).

Enzymatic Pretreatment. With the help of microorganisms as fungi, protozoa, plants, and bacteria, cellulose of the FW can be easily transformed through cellulases, a synergistic enzyme complex. It is called the hydrolysis of cellulose. Therefore, this is known as enzymatic pretreatment. It also helps in the generation of energy (Sukumaran et al., 2005). Enzyme application has several benefits: low capital investment, energy cost-effectiveness, usage of reagent is less and causes no environmental issues. However, low profit is generated as a longer incubation period is needed for the enzymes to carry out the process.

\section{Chemical Pretreatment}

Chemical pretreatment uses chemicals to deviate the chemical and physical properties of lignocellulose in FW. Most researchers are interested in this treatment because of its higher productivity for better bioconversion performance (Nzioka et al., 2016). Some pretreatment classified as chemical pretreatment is alkali pretreatment, acid pretreatment, and ionic liquids pretreatments.
Alkali Pretreatment. The primary purpose of alkali pretreatment is to solubilize lignin in the FW. The commonly used reagents for this pretreatment are potassium, calcium, ammonium, and sodium hydroxides. Sodium hydroxide is known as the most effective reagent among others (Nzioka et al., 2016). Several studies researched the advantages of the alkali pretreatment method.

Alkaline pretreatment using that calcium hydroxide has also been found to be easy and effective. Moreover, calcium hydroxide, $\mathrm{Ca}(\mathrm{OH})_{2}$, is cheap, and the handling method is easy. The FW-alkali ratio must be optimized depending on the solid content and alkaline concentration used for alkaline pretreatment. Ammoniabased alkali pretreatment is famous for its less corrosive, less toxic, and higher recovery rate. Although alkali pretreatment can effectively remove lignin, the major disadvantage is the recovery of the alkaline reagent added.

Acid Pretreatment. During acid pretreatment, hydronium ions can degrade hemicellulose chains into glucose monomers (Lloyd \& Wyman, 2005). Organic acids and inorganic acids can be used. Sulfuric acid and hydrochloric acid are examples of inorganic acids, whereas formic acid and oxalic acid are examples of organic acids. Concentrated acids work efficiently at low temperatures, while dilute acids are effective at high temperatures. However, most of the concentrated acids are harmful and have high maintenance costs. Therefore, dilute acids are commonly used in industrial (Baruah et al., 2018). 
Ionic Liquids. Ionic liquids are solvents with a melting point of less than $100{ }^{\circ} \mathrm{C}$, comprised of cations and anions. In this process, the cations and anions break down cellulose and lignin. As a result, the ionic liquids can undergo a recovery process to be used again. Some of the advantages are that these liquids are non-volatile, non-toxic, and the primary benefit is that the cations and anions react based on the properties of the ionic liquids used (Chen et al., 2017). Thus, ionic liquids are often known as green solvents. The ordinary used ionic liquids are the imidazolium salts (Zhang \& Matsuto, 2010).

\section{Combined Pretreatment}

Combined pretreatment is a combination of more than one pretreatment method. Researches have reported that combined pretreatment has effective results (Salihu \& Alam, 2016). However, some of the pretreatments are proved based on the laboratory scale. Thermal-chemical pretreatment is one of the commonly combined pretreatment practices.

Thermal-Chemical Pretreatment. The thermal-chemical pretreatment method is a method that has a combination of chemical and thermal pretreatment. Kullavanijaya and Chavalparit (2020) stated that for thermalchemical pretreatment, an hour-soaked sample in $3 \%$ sodium hydroxide $(\mathrm{NaOH})$ solution is heated in an autoclave at $\left(121^{\circ} \mathrm{C}\right.$, $103.4 \mathrm{kPa}$ ) for half an hour has the highest soluble chemical oxygen demand (SCOD) content. From the study by Kullavanijaya and Chavalparit (2020), the cellulose content of the sample is has degraded. Studies have been found that the best organic matter solubilization was achieved using thermochemical pretreatments when $\mathrm{NaOH} / \mathrm{L}$ is used as an alkaline agent (Álvarez-Gallego et al., 2015).

Hence, the total solid and volatile solid of the bio-compost sample is decreased. As a result, the water holding capacity and the nutrient content in the soil may be affected. However, ammonium ions $\left(\mathrm{NH}_{4}^{+}\right)$concentration increases because of the rise in organic nitrogen-containing degradation following thermal-chemical pretreatment (Lee et al., 2019). It is an industry-scale pretreatment that was implemented successfully. The results of thermal-chemical pretreatment depend on the form of the substrate, the reaction temperature, and the time of reaction for $\mathrm{FW}$ pretreatment (Salihu \& Alam, 2016).

Moreover, for thermal-chemical pretreatments, the rate of biodegradability is like volatile solid solubilization. Thermal-chemical pretreatments help in the breakdown of macromolecules into monomers (Zhang \& Matsuto, 2010). It enhances the composting process as the worms can easily consume the FW. However, a variety of pretreatment thermalchemical conditions has not been explored subsequently. A combination of thermal and chemical pretreatment methods can improve FW degradation, as reported by Lee et al. (2019). 


\section{FOOD WASTE TREATMENTS}

Proper FW treatment selection benefits the country in the environmental and economic sectors. Anaerobic digestion, composting, incineration, landfilling, and heat-humidity reactions are common FW management methods for handling FW (Gao et al., 2017). Anaerobic digestion (AD) is a valid technology that produces biogas and digestate from the decaying process of organic matter without oxygen. Besides, a landfill is a typical approach with the downside of an enormous property area and a high degree of GHG emission known as $\mathrm{CH}_{4}$ gas.

Incineration is used to generate heat energy which can significantly minimize waste volume (Gao et al., 2017). However, the incineration process is expensive and involves heavy energy use and technology. On the other hand, heat-moisture reaction treatment can effectively remove bacteria and odors (Gao et al., 2017). Chen et al. (2017) have analyzed the discharge of hazardous trace elements by stimulating the heat-moisture treatments on FW samples. Lastly, composting is referred to as decomposition or the natural process of 'rotting' of organic matter under controlled conditions with the help of microorganisms.

\section{Composting as the Treatment}

Composting is known as the most efficient FW treatment, among others. Various researchers have studied and supported this treatment. The number of composting installations has risen since the late 1990s for several reasons (Zhang \& Matsuto, 2010).
Besides, according to Lim et al. (2016), composting had the lowest cost overall compared to other treatments. Alternative approaches have been discovered in the past few years. However, composting has been the best way to fix the FW disposal affecting the environment globally. Composting is carried out to control and reduce $\mathrm{FW}$ in compliance with the SDGs.

Perhaps, composting produces a dark nutrient-rich material from organic matter known as "bio-compost" or "humus" (Nagavallemma et al., 2006). Bio-compost incorporating enhances the soil structure, texture, and tilth (Chauhan et al., 2008). As there are plenty of environmental problems and soil destruction caused by fertilizers and pesticides, bio-composts have developed to be of great significance (Argun et al., 2017). S. S. Kumar (2013) justified that the application of bio-compost is said to promote plant growth and productivity in several crops.

Besides, the production of bio-compost can be an optional method to usual waste disposal methods nowadays and decrease the amount of chemical fertilizer used in agricultural sectors (Ozores-Hampton et al., 2019). The factors that can differentiate for the compost production are the amount of land acquired, the type and quantity of waste to be compost, economic value, and labor force (Apagu, 2012). Some of the common systems at large-scale composting are the windrow method, in-vessel systems, and static pile systems, while small-scale composting systems are compost tumbler, bokashi bin, and VC (Sundberg, 2005). 
A summary of the GHG emission rate between $\mathrm{AD}$, composting, and $\mathrm{VC}$ is presented in Table 1. The emission rate of $\mathrm{CO}_{2}$ and $\mathrm{CH}_{4}$ gas in both $\mathrm{AD}$ and $\mathrm{VC}$ are higher than composting. It defines that the FW decomposition rate is higher in these two FW treatments compared to composting. Besides, nitrous oxide $\left(\mathrm{N}_{2} \mathrm{O}\right)$ largely contributes to $\mathrm{GHG}$ emissions by destroying stratospheric ozone (Aronson \& Allison, 2012). Hence, lower $\mathrm{N}_{2} \mathrm{O}$ emission by $\mathrm{VC}$, causing it to be the environmentalfriendly treatment that is safe and hygienic (Othman et al., 2012).

Table 1

Summary of greenhouse gas $(G H G)$ emission rate between anaerobic digestion (AD), composting, and vermicomposting $(V C)$

\begin{tabular}{ccccc}
\hline $\begin{array}{c}\text { Emission rate } \\
\left(\mathrm{mg} \cdot \mathrm{m}^{-2} \mathrm{~h}^{-1}\right)\end{array}$ & $\mathrm{AD}$ & Composting & $\mathrm{VC}$ & Reference \\
\hline $\mathrm{CO}_{2}$ & 2950 & 882 & 1675 & \\
$\mathrm{CH}_{4}$ & 9.54 & 2.17 & 4.76 & Chan et al. \\
$\mathrm{N}_{2} \mathrm{O}$ & 1.59 & 1.48 & 1.17 & $(2011)$ \\
\hline
\end{tabular}

Note. $\mathrm{CO}_{2}=$ Carbon dioxide; $\mathrm{CH}_{4}=$ Methane; $\mathrm{N}_{2} \mathrm{O}=$ Nitrous oxide

Vermicomposting is the Effective Method. During certain conditions, a mixture of all these methods can make high-quality compost more efficient. From all these methods above, $\mathrm{VC}$ is known as an effective technique in composting. $\mathrm{VC}$ is a more environmentally sustainable natural method for FW (Othman et al., 2012). VC is not the decomposition by microorganisms, yet it is an enzymatic deterioration by the earthworm digestive system. VC uses worms to consume FW. Earthworms can consume almost all types of FW, and the amount of food is comparable with their body weight per day. Soil nutrients are rich in the excrete (castings) from the worms.

Earthworms feed on and migrate through the digestive system of biological waste and excrete it in granule shape. Good quality composts can be produced by VC that involves no physical material turning. $\mathrm{VC}$ is an excellent way to turn diverse solid residue types into soil additives (Cao et al., 2016). Earthworms enhance the growth of bacteria and actinomycetes through the passage of soil by them. Actinomycetes are produced at a higher rate in the presence of worms (Nagavallemma et al., 2006).

It is widely embraced around the globe, including Asia, Africa, Europe, and North and South America (Arancon et al., 2008). In the United States, potential benefits of VC, such as stabilization, have been extensively publicized (Cao et al., 2016). Besides, there are more than 1800 species of earthworms worldwide (Arancon et al., 2004). Among them, Savigny (Eisenia fetida) is known as the common worm 
used in VC. It is also known as "manure worm" ,"compost worm", "red wiggler", and "redworm". Redworm is considered one of the toughest worms that can easily adapt to its surroundings.

Redworms are commonly found all around the world, especially on Canadian farms. It can be found easily on piles of manure that are left for a long time. Redworms have rings on their body that is made from circular muscles. The muscle expands, and contracts, making the worms move as they shorten and lengthen the body (Angima et al., 2011). This phenomenon gives them an extraordinary feature as they can move in all directions. In addition, moisture is needed for the lubrication of the worm's motion. All these features well suited them for breaking down organic matter.

Redworms are also known as multifaceted VC earthworms because they can resist high temperatures and has high reproductive rates (Munroe et al., 2007). Besides, their food ingestion rate is high as well. On the other hand, compost worms have some requirements. Firstly, they need an optimum living environment called bedding. Second, they need a constant food supply. Then, moisture content should be controlled by approximately more than half water content by weight percentage. Third, a proper air supply is needed for the worms as living things. Finally, they cannot sustain themselves in extreme temperatures.

\section{BIO-COMPOST EFFECT ON SOIL PROPERTIES}

The primary function of bio-compost is to increase soil fertility. Based on the studies and researches regarding the benefits of bio-compost as a soil additive, bio-compost has influenced the soil properties as stated below.

\section{Soil Fertility}

Loss and imbalance of organic matter in the soil affect global production in agriculture (Dastpak et al., 2020). Conversely, a rise in organic matter has a significant impact on the soil. Bio-compost from FW provides high nutrient values that minimize the usage of chemical fertilizer to increase soil fertility. The usage of bio-compost has been proved to support plant growth in various studies (Kuang et al., 2012).

\section{Physical Properties}

Lower bulk density increases the overall porosity of the soil. It is one of the advantages of bio-compost on soil properties. The increase in soil density and the overall porosity can be achieved by bio-compost which helps lower the soil density and increase the organic matter. Besides, water retention of the soil can be further improved by adding bio-compost to the soil. Biocompost applied to the soil with increased water capacity can usually prevent the drainage of excess nutrients into nearby soil resources compared to sandy soils with higher porosity. Therefore, bio-compost 
can be used as an enhancer for the soil in terms of physical properties and sometimes boost the production of the crops. Thus, soil nutrients and soil properties are improved and preserved with bio-compost (Ahmad et al., 2016).

\section{Chemical Properties}

Moisture Content. The moisture content impacts bacteria and prevents useful microorganisms that serve as composters if their moisture content is too poor. However, the anaerobic state creates an unpleasant odor when the humidity content is too high, disrupting the VC process. VC process would be successful at a moisture content between 50 and 60\% (Bhat et al., 2017). However, the properties of compost, such as humidity, $\mathrm{pH}$ value, and carbon to nitrogen $(\mathrm{C}: \mathrm{N})$ ratio, are influenced by the type of FW. The main benefit of bio-compost on soil properties is that it can conserve more water than mineral soil, preventing the plants from wilting quickly. With optimum moisture content, the rate of mineralization and decomposition is faster. Apart from that, bio-compost can simultaneously minimize water and fertilizer usage as bio-compost has higher moisture content with various nutrients (Ozores-Hampton et al., 2019).

Soil Nutrients. Compared to Bhat et al. (2017), VC has increased in all total macronutrients and a drop in total sulfide. Phosphorus $(\mathrm{P})$, nitrogen $(\mathrm{N})$, and potassium $(\mathrm{K})$ were shown to be crucial components of the plant growth and production processes (Iqbal et al., 2012). Magnesium (Mg) minimizes heavy metal stress by adding to plant photosynthesis (Pierre et al., 2020). Traditionally, $\mathrm{N}$ has been known as the primary plant nutrient. The proteins building cell and plant tissue are an integral part. Besides, $\mathrm{N}$ is also the leading determinant of plant growth of all the primary plant nutrients. Plants lacking $\mathrm{N}$ have yellowish leaves and steep growth. Plant growth and crop production typically increase with $\mathrm{N}$ content in soils, as it is one of the essential elements in chlorophyll.

Therefore, the increased use of the soil from VC provides a larger amount of $\mathrm{N}$ for growth plants (Othman et al., 2012). N continues to increase as the dry mass increase due to the $\mathrm{CO}_{2}$ emissions, wastewater depletion by evaporation, and nitrogen-fixing operations. The $\mathrm{C}: \mathrm{N}$ ratio can influence the FW decomposition rate during the composting process (Garg et al., 2012). C is used as the energy supply, whereas $\mathrm{N}$ creates proteins during the composting phase using microorganisms. The higher the $\mathrm{C}$ : $\mathrm{N}$ ratio, the lower the decay process, and $\mathrm{N}$ is immobilized throughout the composting period. However, FW has an adequate ratio of $\mathrm{C}: \mathrm{N}$ that can compost the substances (Wapa et al., 2014).

Soil pH. Bio-compost influences soil $\mathrm{pH}$ depending on the soil's original $\mathrm{pH}$ and the $\mathrm{pH}$ of the bio-compost. Using bio-compost as neutral or slightly alkalizing $\mathrm{pH}$ or $\mathrm{pH}$ buffer can increase soil acidity, especially in soils of higher concentrations (Othman et al., 2012). In addition, the changes in $\mathrm{pH}$ can lead to changes in soil particles' surface 
load that affects their ability to link the available nutrients. Therefore, to produce an effective bio-compost, $\mathrm{pH}$ is an essential consideration.

Electrical Conductivity. Plant excess salt such as sodium ion $\left(\mathrm{Na}^{+}\right)$, magnesium ion $\left(\mathrm{Mg}^{2+}\right)$, potassium ion $\left(\mathrm{K}^{+}\right)$, and chloride ion $\left(\mathrm{Cl}^{-}\right)$have a substantial adverse effect on soil structure. Electrical conductivity (EC) in the soil can be improved by biocompost. Bio-compost has a high amount of salt, which is proportional to redworms consumption. Over time, EC levels in the soil will decrease because of crop nutrient absorption and leaching. Therefore, the addition of bio-compost can increase the EC level in the soil.

\section{BIO-COMPOST EFFECTS ON THE GROWTH OF ABELMOSCHUS ESCULENTUS L.}

Vermicompost may have physical and chemical properties that affect plant development and overall morphology in various ways. Vermicompost can be used on a variety of crops, including field and horticultural crops. The use of vermicompost in conjunction with inorganic fertilizers increased crop yields in crops such as potato, rapeseed, groundnut, black gram, rice, mulberry, and marigold (A. Kumar et al., 2018). Positive effects from the addition of vermicompost to the soil in tomato crops have also been reported (Gutiérrez-Miceli et al., 2007). As a result, vermicompost has the potential to be a valuable ingredient in sustainable agriculture.
Abelmoschus esculentus L. is a flucreating plant of the malevolent family. The most common name of this plant is either okra or Lady's finger (Muqtadir et al., 2019). The plant is grown around the world in tropical, subtropical, and mild temperate areas. Throughout the tropics, it is known as a summer vegetable. Besides, the $A$. esculentus L. is acknowledged as the oldest crop (Gemede, 2015). N is a vital element that helps in the synthesis of useful nutrients and cell development.

The plant growth and pod of $A$. esculentus L. will increase with the supply of N. P enhances fruiting and fruit development and is directly involved in the living mechanisms of a plant. $\mathrm{N}, \mathrm{P}$, and $\mathrm{K}$ rates and ratios required by the $A$. esculentus L. have not been studied extensively. Zinc $(\mathrm{Zn})$ and boron (B) are some of the main micronutrients needed by the $A$. esculentus L. based on the studies (Sajid et al., 2012). The deficiency of $\mathrm{Zn}$ affects the formation of strip tissue on the leaves. The presence of B increases with the decreasing $\mathrm{pH}$ value of the soil (Waqas et al., 2018).

Sodium $(\mathrm{Na})$, magnesium $(\mathrm{Mg})$, and calcium $(\mathrm{Ca})$ are also known to be the principal elements in the lady's finger pods. Iron (Fe), manganese ( $\mathrm{Mn}$ ), and nickel (Ni) were also reported to be found on the A. esculentus L. (Moyin-Jesu, 2007). Research on $A$. esculentus L. cultivated with varying proportions of municipal solid waste vermicompost (MSWVC) amendment ratios $(0 \%, 20 \%, 40 \%, 60 \%, 80 \%$, and $100 \%)$ with agricultural soil was conducted. Based on the analysis, yield and physiological 
reactions of $A$. esculentus $\mathrm{L}$. were the lowest at $0 \%$ and highest at $60 \%$ (Srivastava et al., 2018).

The previous study has found that the use of plant nutrients by $\mathrm{VC}$ is improved (Nagavallemma et al., 2006), and it makes the use of water more effective for soil reception (Ellery \& Kai, 2010). Gurav and Pathade (2011) suggested that castings by worms will be high content in N, P, K, and other micronutrient based on the FW chosen. Therefore, it is justified that the addition of bio-compost increases the yield of A. esculentus L. (Muhammad Firdaus et al., 2018). Plant growth determines the quality of bio-compost in terms of nutrient content. A wide variety of essential nutrients in plants which is not provided by chemical fertilizers can be supplied by good quality bio-compost.

The research indicates that bio-compost may also be used to generate an organic change to soil with strong yields for $A$. esculentus L. (Srivastava et al., 2018). Overall changes in soil, carotenoids, and protein content have been increased substantially with $20 \%, 40 \%$, and $60 \%$ with 65 days with germinations. In addition, $\mathrm{VC}$ is proven to enhance the water holding capacity, nutrient profile, and soil microbial response in the lady's finger plant (Weber et al., 2014).

To sum up, bio-compost can nurture a particular plant species. Some essential plant metabolites like N, P, and $\mathrm{K}$ in FW are transformed into chemical means that are more accessible for the plants during material transit through the worms of the gut. Furthermore, several valuable nutrients needed by plants have been shown to have been significantly rich in bio-compost (Cao et al., 2016). Thus, the addition of biocompost increases the plant growth and performance of the fruit produced (Arancon et al., 2003).

\section{CONCLUSION}

This review article has accumulated the primary details that can be applied in the research of bio-compost as soil additive by food waste (FW) pretreatment on the Abelmoschus esculentus L. growth. Firstly, the advantages of composting FW help reduce waste and act as organic fertilizer. Based on the compost methods reviewed above, the vermicompost (VC) method is the most convenient composting method for this research. This method requires less labor and produces high-quality compost compared to others. Bio-compost produced by $\mathrm{VC}$ can be an alternative to chemical fertilizer which is pricier. Pretreatment methods on the FW provide effective results during $\mathrm{VC}$.

\section{ACKNOWLEDGEMENTS}

This research has received technical and financial support from Knowledge Transfer Grant Scheme (Vote Number: 9437581), UC Collaborative Fund (Vote Number: GBG191789), and UPM Publication Fund (Vote Number: 9001103), respectively. 


\section{REFERENCES}

Ahmad, A. A., Radovich, T. J. K., Nguyen, H. V., Uyeda, J., Arakaki, A., Cadby, J., Paull, R., Sugano, J., \& Teves, G. (2016). Use of organic fertilizers to enhance soil fertility, plant growth, and yield in a tropical environment. https://www. intechopen.com/chapters/50720

Albanell, E., Plaixats, J., \& Cabrero, T. (1988). Chemical changes during vermicomposting (Eisenia fetida) of sheep manure mixed with cotton industrial wastes. Biology and Fertility of Soils, 6(3), 266-269. https://doi.org/10.1007/ BF00260823

Álvarez-Gallego, C. J., Fdez-Güelfo, L. A., Romero Aguilar, M. de los Á., \& García, L. I. R. (2015). Thermochemical pretreatments of organic fraction of municipal solid waste from a mechanical-biological treatment plant. International Journal of Molecular Sciences, 16(2), 3769-3782. https://doi.org/10.3390/ ijms 16023769

Angima, S., Noack, M., \& Noack, S. (2011). Composting with worms. https://ir.library. oregonstate.edu/concern/open_educational_ resources/p5547r80s

Apagu, A. B. (2012). Recycling biodegradable waste using composting technique. Journal of Environmental Science and Resources Management, 4, 40-49.

Arancon, N. Q., Edwards, C. A., Atiyeh, R., \& Metzger, J. D. (2004). Effects of vermicomposts produced from food waste on the growth and yields of greenhouse peppers. Bioresource Technology, 93(2), 139-144. https://doi. org/10.1016/j.biortech.2003.10.015

Arancon, N. Q., Edwards, C. A., Babenko, A., Cannon, J., Galvis, P., \& Metzger, J. D. (2008). Influences of vermicomposts, produced by earthworms and microorganisms from cattle manure, food waste and paper waste, on the germination, growth and flowering of petunias in the greenhouse. Applied Soil Ecology, 39(1), 91-99. https://doi. org/10.1016/j.apsoil.2007.11.010

Arancon, N. Q., Edwards, C. A., Bierman, P., Metzger, J. D., Lee, S., \& Welch, C. (2003). Effects of vermicomposts on growth and marketable fruits of field-grown tomatoes, peppers and strawberries. Pedobiologia, 47(5-6), 731-735. https://doi.org/10.1078/0031-4056-00251

Argun, Y. A., Karacali, A., Calisir, U., \& Kilinc, N. (2017). Composting as a waste management method. Journal of International Environmental Application and Science, 12(3), 244-255.

Aronson, E. L., \& Allison, S. D. (2012). Meta-analysis of environmental impacts on nitrous oxide release in response to $\mathrm{N}$ amendment. Frontiers in Microbiology, 3, 272. https://doi.org/10.3389/ fmicb.2012.00272

Arvanitoyannis, I. S., Kassaveti, A., \& Ladas, D. (2008). Food waste treatment methodologies. In Waste management for the food industries (pp. 345-410). Elsevier Inc. https://doi.org/10.1016/ B978-012373654-3.50009-2

Baruah, J., Nath, B. K., Sharma, R., Kumar, S., Deka, R. C., Baruah, D. C., \& Kalita, E. (2018). Recent trends in the pretreatment of lignocellulosic biomass for value-added products. Frontiers in Energy Research, 6, 141. https://doi.org/10.3389/ fenrg.2018.00141

Batista Meneses, D., Montes de Oca-Vásquez, G., Vega-Baudrit, J. R., Rojas-Álvarez, M., CorralesCastillo, J., \& Murillo-Araya, L. C. (2020). Pretreatment methods of lignocellulosic wastes into value-added products: Recent advances and possibilities. Biomass Conversion and Biorefinery. https://doi.org/10.1007/s13399020-00722-0

Bernstad, A., \& la Cour Jansen, J. (2012). Separate collection of household food waste for anaerobic degradation - Comparison of different techniques 
from a systems perspective. Waste Management, 32(5), 806-815. https://doi.org/10.1016/j. wasman.2012.01.008

Bhat, S. A., Singh, J., \& Vig, A. P. (2017). Instrumental characterization of organic wastes for evaluation of vermicompost maturity. Journal of Analytical Science and Technology, 8(1), 2. https://doi. org/10.1186/s40543-017-0112-2

Boulter, J. I., Boland, G. J., \& Trevors, J. T. (2000). Compost: A study of the development process and end-product potential for suppression of turfgrass disease. World Journal of Microbiology and Biotechnology, 16(2), 115-134. https://doi. org/10.1023/A:1008901420646

Cao, W., Vaddella, V., Biswas, S., Perkins, K., Clay, C., Wu, T., Zheng, Y., Ndegwa, P., \& Pandey, P. (2016). Assessing the changes in E. coli levels and nutrient dynamics during vermicomposting of food waste under lab and field scale conditions. Environmental Science and Pollution Research, 23(22), 23195-23202. https://doi.org/10.1007/ s11356-016-7528-x

Chan, Y. C., Sinha, R. K., \& Wang, W. (2011). Emission of greenhouse gases from home aerobic composting, anaerobic digestion and vermicomposting of household wastes in Brisbane (Australia). Waste Management and Research, 29(5), 540-548. https://doi. org/10.1177/0734242X10375587

Chauhan, N., Singh, M. P., Singh, A., Singh, A. K., Chauhan, S. S., \& Singh, S. B. (2008). Effect of biocompost application on sugarcane crop. Sugar Tech, 10(2), 174-176. https://doi.org/10.1007/ s12355-008-0032-y

Chen, H., Liu, J., Chang, X., Chen, D., Xue, Y., Liu, P., Lin, H., \& Han, S. (2017). A review on the pretreatment of lignocellulose for highvalue chemicals. Fuel Processing Technology, 160, 196-206. https://doi.org/10.1016/j. fuproc.2016.12.007
Dastpak, H., Pasalari, H., Jafari, A. J., Gholami, M., \& Farzadkia, M. (2020). Improvement of Co-Composting by a combined pretreatment Ozonation/Ultrasonic process in stabilization of raw activated sludge. Scientific Reports, 10(1), 1070. https://doi.org/10.1038/s41598020-58054-y

Deepanraj, B., Sivasubramanian, V., \& Jayaraj, S. (2017). Effect of substrate pretreatment on biogas production through anaerobic digestion of food waste. International Journal of Hydrogen Energy, 42(42), 26522-26528. https://doi. org/10.1016/j.ijhydene.2017.06.178

Delgenes, J. P., Penaud, V., \& Moletta, R. (2003). Pretreatments for the enhancement of anaerobic digestion of solid wastes. ChemInform, 34(13). https://doi.org/10.1002/chin.200313271

Duque, A., Manzanares, P., \& Ballesteros, M. (2017). Extrusion as a pretreatment for lignocellulosic biomass: Fundamentals and applications. Renewable Energy, 114(Part B), 1427-1441. https://doi.org/10.1016/j.renene.2017.06.050

Ellery, D. J., \& Kai, T. C. (2010). Vermicomposting projects in Hong Kong. In C. A. Edwards, N. Q. Arancon, \& R. L. Sherman (Eds.), Vermiculture technology: Earthworms, organic wastes, and environmental management (pp. 497-529). CRC Press. https://doi.org/10.1201/b10453

Gandhi, P., Paritosh, K., Pareek, N., Mathur, S., Lizasoain, J., Gronauer, A., Bauer, A., \& Vivekanand, V. (2018). Multicriteria decision model and thermal pretreatment of hotel food waste for robust output to biogas: Case study from city of Jaipur, India. BioMed Research International, 2018, 9416249. https://doi. org/10.1155/2018/9416249

Gao, A., Tian, Z., Wang, Z., Wennersten, R., \& Sun, Q. (2017). Comparison between the technologies for food waste treatment. Energy Procedia, 105, 3915-3921. https://doi.org/10.1016/j. egypro.2017.03.811 
Garg, V. K., Suthar, S., \& Yadav, A. (2012). Management of food industry waste employing vermicomposting technology. Bioresource Technology, 126, 437-443. https://doi. org/10.1016/j.biortech.2011.11.116

Gemede, H. F. (2015). Nutritional quality and health benefits of okra (Abelmoschus esculentus): A review. Journal of Food Processing and Technology, 6(6), 1000458. https://doi. org/10.4172/2157-7110.1000458

Gurav, M. V, \& Pathade, G. R. (2011). Production of vermicompost from temple waste (Nirmalya): A case study. Universal Journal of Environmental Research and Technology, 1(2), 182-192.

Gutiérrez-Miceli, F. A., Santiago-Borraz, J., Montes Molina, J. A., Nafate, C. C., Abud-Archila, M., Oliva Llaven, M. A., Rincón-Rosales, R., \& Dendooven, L. (2007). Vermicompost as a soil supplement to improve growth, yield and fruit quality of tomato (Lycopersicum esculentum). Bioresource Technology, 98(15), 2781-2786. https://doi.org/10.1016/j.biortech.2006.02.032

Hao, H. T. N., Karthikeyan, O. P., \& Heimann, K. (2015). Bio-refining of carbohydrate-rich food waste for biofuels. Energies, 8(7), 6350-6364. https://doi.org/10.3390/en8076350

Iqbal, M. K., Khan, R. A., Nadeem, A., \& Hussnain, A. (2012). Comparative study of different techniques of composting and their stability evaluation in municipal solid waste. Journal of the Chemical Society of Pakistan, 34(2), 273-282.

Jain, S., Newman, D., Cepeda-Márquez, R., \& Zeller, K. (2018). Global food waste management: An implementation guide for cities. https:// www.worldbiogasassociation.org/wp-content/ uploads/2018/05/Global-Food-WasteManagement-Full-report-pdf.pdf

Kamaruzzaman, F., Zain, S. M., Saad, N. F. M., Basri, H., \& Basri, N. E. A. (2018). Effective use of indigenous microorganism (IMO) in composting a mixture of food and yard wastes on an industrial scale. Jurnal Kejuruteraan, 1(5), 53-58.

Krishna, D., \& Kalamdhad, A. S. (2014). Pretreatment and anaerobic digestion of food waste for high rate methane production - A review. Journal of Environmental Chemical Engineering, 2(3), 1821-1830. https://doi. org/10.1016/j.jece.2014.07.024

Kuang, B., Mahmood, H. S., Quraishi, M. Z., Hoogmoed, W. B., Mouazen, A. M., \& van Henten, E. J. (2012). Sensing soil properties in the laboratory, in situ, and on-line. A review. In Advances in agronomy (1st ed., Vol. 114, pp. 155-223). Elsevier Inc. https://doi.org/10.1016/ B978-0-12-394275-3.00003-1

Kullavanijaya, P., \& Chavalparit, O. (2020). The effect of ensiling and alkaline pretreatment on anaerobic acidification of Napier grass in the leached bed process. Environmental Engineering Research, 25(5), 668-676. https:// doi.org/10.4491/eer.2019.231

Kumar, A., Prakash, C. H. B., Brar, N. S., \& Kumar, B. (2018). Potential of vermicompost for sustainable crop production and soil health improvement in different cropping systems. International Journal of Current Microbiology and Applied Sciences, 7(10), 1042-1055. https:// doi.org/10.20546/ijcmas.2018.710.116

Kumar, S. S. (2013). Eco-friendly practice of utilization of food wastes. International Journal of Pharmaceutical Science Invention, 2(1), 14-17.

Lee, W., Park, S., Cui, F., \& Kim, M. (2019). Optimizing pre-treatment conditions for anaerobic co-digestion of food waste and sewage sludge. Journal of Environmental Management, 249, 109397. https://doi.org/10.1016/j. jenvman.2019.109397

Lim, W. J., Chin, N. L., Yusof, A. Y., Yahya, A., \& Tee, T. P. (2016). Food waste handling in Malaysia 
and comparison with other Asian countries. International Food Research Journal, 23(Suppl), S1-S6.

Lloyd, T. A., \& Wyman, C. E. (2005). Combined sugar yields for dilute sulfuric acid pretreatment of corn stover followed by enzymatic hydrolysis of the remaining solids. Bioresource Technology, 96(18), 1967-1977. https://doi.org/10.1016/j. biortech.2005.01.011

Moyin-Jesu, E. I. (2007). Use of plant residues for improving soil fertility, pod nutrients, root growth and pod weight of okra (Abelmoschus esculentum L.). Bioresource Technology, 98(11), 2057-2064. https://doi.org/10.1016/j.biortech.2006.03.007

Muhammad Firdaus, A. R., Abu Samah, M. A., \& Abd Hamid, K. B. (2018). CHNS analysis towards food waste in composting. Journal CleanWAS, 2(1), 6-10. https://doi.org/10.26480/ jcleanwas.01.2018.06.10

Munroe, G., Scott, J., Burlington, C., Scotia, N., Holsteins, K., \& Pre, G. (2007). Manual of on-farm vermicomposting and vermiculture. https://www.eawag.ch/fileadmin/Domain1/ Abteilungen/sandec/E-Learning/Moocs/ Solid_Waste/W4/Manual_On_Farm _ Vermicomposting_Vermiculture.pdf

Muqtadir, M., Islam, M., Haque, T., \& Nahar, A. (2019). Growth and yield of okra influenced by different types of fertilizers and netting. Progressive Agriculture, 30, 1-9. https://doi. org/10.3329/pa.v30i0.41550

Nagavallemma, K., Wani, S., Stephane, L., Padmaja, V., Vineela, C., \& Babu, R. M. (2006). Vermicomposting: Recycling wastes into valuable organic fertilizer. https://www. researchgate.net/publication/26513646_ Vermicomposting_recycling_wastes_into_ valuable_organic_fertilizer

Nzioka, A. M., Hwang, H. U., Kim, M. G., Troshin, A. G., Caozheng, Y., \& Kim, Y. J. (2016). Experimental investigation of drying process for mixed municipal solid waste: Case study of wastes generated in Nairobi, Kenya. International Journal of Advances in Agricultural and Environmental Engineering, 3(1), 87-91. https://doi.org/10.15242/ijaaee. er01160039

Othman, N., Irwan, J. M., \& Roslan, M. A. (2012). Vermicomposting of food waste. International Journal of Integrated Engineering, 4(2), 39-48.

Ozores-Hampton, M., Bewick, T. A., Stoffella, P., Cantliffe, D. J., \& Obreza, T. A. (2019). Municipal solid waste (MSW) compost maturity influence on weed seed germination. HortScience, 31(4), 577e-577. https://doi. org/10.21273/hortsci.31.4.577e

Paritosh, K., Kushwaha, S. K., Yadav, M., Pareek, N., Chawade, A., \& Vivekanand, V. (2017). Food waste to energy: An overview of sustainable approaches for food waste management and nutrient recycling. BioMed Research International, 2017, 2370927. https://doi. org/10.1155/2017/2370927

Pierre, D., Kodandoor, S. C., \& Naik, P. (2020). Vermicomposting of food waste using exotic species of earthworms "Eudriluseugeniae" at Mangalagangonthri. Rwanda Journal of Engineering, Science, Technology and Environment, 3(1). https://doi.org/10.4314/ rjeste.v3i1.8

Ragazzi, M., Rada, E. C., Panaitescu, V., \& Aposto, T. (2007). Municipal solid waste pre-treatment: A comparison between two dewatering options. WIT Transactions on Ecology and the Environment, 102, 943-949. https://doi. org/10.2495/SDP070902

Sajid, M., Khan, M. A., Rab, A., Shah, S. N. M., Arif, M., Jan, I., Hussain, Z., \& Mukhtiar, M. (2012). Impact of nitrogen and phosphorus on seed yield and yield components of okra cultivars. Journal of Animal and Plant Sciences, 22(3), 704-707. 
Salihu, A., \& Alam, M. Z. (2016). Pretreatment methods of organic wastes for biogas production. Journal of Applied Sciences, 16(3), 124-137. https://doi.org/10.3923/jas.2016.124.137

Sasaki, N., Suehara, K. I., Kohda, J., Nakano, Y., \& Yano, T. (2003). Effects of $\mathrm{C} / \mathrm{N}$ ratio and $\mathrm{pH}$ of raw materials on oil degradation efficiency in a compost fermentation process. Journal of Bioscience and Bioengineering, 96(1), 47-52. https://doi.org/10.1263/jbb.96.47

Seidl, P. R., \& Goulart, A. K. (2016). Pretreatment processes for lignocellulosic biomass conversion to biofuels and bioproducts. Current Opinion in Green and Sustainable Chemistry, 2, 48-53. https://doi.org/10.1016/j.cogsc.2016.09.003

Shen, D. S., Yang, Y. Q., Huang, H. L., Hu, L. F., \& Long, Y. Y. (2015). Water state changes during the composting of kitchen waste. Waste Management, 38(1), 381-387. https://doi. org/10.1016/j.wasman.2015.01.011

Slorach, P. C., Jeswani, H. K., Cuéllar-Franca, R., \& Azapagic, A. (2019). Environmental sustainability of anaerobic digestion of household food waste. Journal of Environmental Management, 236, 798-814. https://doi. org/10.1016/j.jenvman.2019.02.001

Song, C., Li, M., Qi, H., Zhang, Y., Liu, D., Xia, X., Pan, H., \& Xi, B. (2018). Impact of anti-acidification microbial consortium on carbohydrate metabolism of key microbes during food waste composting. Bioresource Technology, 259, 1-9. https://doi.org/10.1016/j. biortech.2018.03.022

Srivastava, V., Gupta, S. K., Singh, P., Sharma, B., \& Singh, R. P. (2018). Biochemical, physiological, and yield responses of lady's finger (Abelmoschus esculentus L.) grown on varying ratios of municipal solid waste vermicompost. International Journal of Recycling of Organic Waste in Agriculture, 7(3), 241-250. https://doi. org/10.1007/s40093-018-0210-1
Sukumaran, R. K., Singhania, R. R., \& Pandey, A. (2005). Microbial cellulases - Production, applications and challenges. Journal of Scientific and Industrial Research, 64(11), 832-844.

Sun, W., Huang, G. H., Zeng, G., Qin, X., \& Sun, X. (2009). A stepwise-cluster microbial biomass inference model in food waste composting. Waste Management, 29(12), 2956-2968. https://doi. org/10.1016/j.wasman.2009.06.023

Sundberg, C. (2005). Improving compost process efficiency by controlling aeration, temperature and $\mathrm{pH}$ [Doctoral's thesis, Swedish University of Agricultural Sciences]. SLU Publication Database. https://pub.epsilon.slu.se/950/

Sundberg, C., Yu, D., Franke-Whittle, I., Kauppi, S., Smårs, S., Insam, H., Romantschuk, M., \& Jönsson, H. (2013). Effects of pH and microbial composition on odour in food waste composting. Waste Management, 33(1), 204-211. https://doi. org/10.1016/j.wasman.2012.09.017

Tun, M. M., \& Juchelková, D. (2019). Drying methods for municipal solid waste quality improvement in the developed and developing countries: A review. Environmental Engineering Research, 24(4), 529-542. https://doi.org/10.4491/ eer. 2018.327

Vanneste, J., Ennaert, T., Vanhulsel, A., \& Sels, B. (2017). Unconventional pretreatment of lignocellulose with low-temperature plasma. ChemSusChem, 10(1), 14-31. https://doi. org/10.1002/cssc.201601381

Vinoth Kumar, K., \& Kasturi Bai, R. (2008). Solar greenhouse assisted biogas plant in hilly region - A field study. Solar Energy, 82(10), 911-917. https://doi.org/10.1016/j.solener.2008.03.005

Wapa, J. M., Kwari, J. D., \& Ibrahim, S. A. (2014). Effects of Biochar, Mokusakueki and Bokashi application on soil nutrients, yields and qualities of sweet potato. Journal of Agriculture and Environmental Sciences, 3(2), 299-314. 
Waqas, M., Nizami, A. S., Aburiazaiza, A. S., Barakat, M. A., Rashid, M. I., \& Ismail, I. M. I. (2018). Optimizing the process of food waste compost and valorizing its applications: A case study of Saudi Arabia. Journal of Cleaner Production, 176, 426-438. https://doi. org/10.1016/j.jclepro.2017.12.165

Weber, J., Kocowicz, A., Bekier, J., Jamroz, E., Tyszka, R., Debicka, M., Parylak, D., \& Kordas, L. (2014). The effect of a sandy soil amendment with municipal solid waste (MSW) compost on nitrogen uptake efficiency by plants. European Journal of Agronomy, 54, 54-60. https://doi. org/10.1016/j.eja.2013.11.014

Wong, J. W. C., Fung, S. O., \& Selvam, A. (2009). Coal fly ash and lime addition enhances the rate and efficiency of decomposition of food waste during composting. Bioresource Technology, 100(13), 3324-3331. https://doi.org/10.1016/j. biortech.2009.01.063

Xu, N., Liu, S., Xin, F., Zhou, J., Jia, H., Xu, J., Jiang, M., \& Dong, W. (2019). Biomethane production from lignocellulose: Biomass recalcitrance and its impacts on anaerobic digestion. Frontiers in Bioengineering and Biotechnology, 7, 191. https://doi.org/10.3389/fbioe.2019.00191
Yin, Y., Liu, Y. J., Meng, S. J., Kiran, E. U., \& Liu, Y. (2016). Enzymatic pretreatment of activated sludge, food waste and their mixture for enhanced bioenergy recovery and waste volume reduction via anaerobic digestion. Applied Energy, 179, 1131-1137. https://doi. org/10.1016/j.apenergy.2016.07.083

Yu, H., \& Huang, G. H. (2009). Effects of sodium acetate as a $\mathrm{pH}$ control amendment on the composting of food waste. Bioresource Technology, 100(6), 2005-2011. https://doi. org/10.1016/j.biortech.2008.10.007

Zhang, H. J., \& Matsuto, T. (2010). Mass and element balance in food waste composting facilities. Waste Management, 30(8-9), 1477-1485. https:// doi.org/10.1016/j.wasman.2010.02.029

Zheng, Y., Zhao, J., Xu, F., \& Li, Y. (2014). Pretreatment of lignocellulosic biomass for enhanced biogas production. Progress in Energy and Combustion Science, 42(1), 35-53. https:// doi.org/10.1016/j.pecs.2014.01.001 